\title{
Modeling the influence of body size on trace element accumulation in the mussel Mytilus edulis
}

\author{
Wen-Xiong Wang*, Nicholas S. Fisher** \\ Marine Sciences Research Center, State University of New York, Stony Brook, New York 11794-5000, USA
}

\begin{abstract}
We measured assimilation efficiencies (AEs) from ingested algal food, uptake rates from the dissolved phase, and efflux rate constants of 4 trace elements ( $\mathrm{Cd}, \mathrm{Co}$, Se and $\mathrm{Zn}$ ) in 3 size classes $(1.5,2.5$, and $5.0 \mathrm{~cm})$ of the mussel Mytilus edulis. AEs of Se and $\mathrm{Zn}$ remained constant among the 3 body sizes. AEs of Cd decreased with increasing body size, whereas AEs of Co increased with body size. The rate constant of metal uptake from the dissolved phase decreased with increasing body size, but the calculated metal absorption efficiencies remained relatively constant or increased slightly in larger mussels. Efflux rate constants were comparable among the 3 body sizes, except for $\mathrm{Cd}$ which was lost about 2 times faster in the smaller mussels than in the largest mussels. A bioenergetic-based kinetic model was used to calculate the allometric coefficient (b) of metal accumulation with mussel body size; predicted $b$ values were comparable to field measurements. However, b increased exponentially with the growth rate constant, indicating that no single b value is likely to be observed in nature for a specific metal. The growth rate constant is needed for the model to predict metal concentration and allometry of metal accumulation in mussels, especially for smaller mussels. The relative importance of trace element uptake from the dissolved phase versus particulate ingestion in the overall metal uptake in mussels was relatively independent of mussel body size, primarily because the influx rates from the dissolved phase and from food were comparably related to body size.
\end{abstract}

KEY WORDS: Allometry · Mussels · Bioaccumulation · Modeling $\cdot$ Cadmium $\cdot$ Cobalt $\cdot$ Selenium · Zinc

\section{INTRODUCTION}

Marine mussels, especially Mytilus edulis, have been extensively employed as biomonitors of coastal contamination in many parts of the world. Since 1986 , the US National Status and Trends (NS\&T) Program has annually monitored trace element concentrations in mussels and oysters from coastal waters of the US. Unambiguous interpretation of these monitoring data requires an understanding of the factors underlying the variability in trace element concentration in mussels. Biological factors, such as growth or body size/ age, can contribute to variability of metal accumulation (Langston \& Spence 1995, Wang \& Fisher 1997). Consequently monitoring programs sample mussels of uni-

\footnotetext{
- Present address: Department of Biology, The Hong Kong University of Science and Technology, Clear Water Bay, Kowloon, Hong Kong

"Addressee for correspondence.

E-mail: nfisher@ccmail.sunysb.edu
}

form size (typically 5 to $6 \mathrm{~cm}$ shell length) in winter to avoid variability due to body size and spawning (Phillips 1980, O'Connor et al. 1994).

Boyden (1974) reviewed the size-dependence of metal concentration in marine bivalves and found that it covers the full range of possibilities, that is, metal concentrations can increase, decrease, or remain constant with body size. Although Boyden (1974, 1977) proposed that the allometric relationships remain rather constant for a given combination of organism and metal, it has been frequently observed that these relationships can in fact vary greatly among locations or seasons. For example, for $\mathrm{Cd}$ and $\mathrm{Zn}$ in mussels positive (Harris et al. 1979, Lobel \& Wright 1982), negative (Phillips 1976, Boyden 1977, Cossa et al. 1980, Borchardt et al. 1988), or no (Phillips 1976, Boyden 1977. Fischer 1983, Popham \& d'Auria 1983) correlations of metal concentration in mussels with body size have been reported. Most recently, Riget et al. (1996) measured trace element concentrations in mussels collected from pristine Arctic environments. Both positive 
(Cd) and negative (Se) relationships between element concentration and body size were observed. For other metals ( $\mathrm{Zn}, \mathrm{Cr}$ and $\mathrm{Hg}$ ), concentrations were relatively independent of body size. The allometric relationship is likely related to the growth rate of mussels, ambient metal concentrations and other environmental conditions, but mechanistic explanations for these patterns have not emerged (Langston \& Spence 1995).

Recently, a bioenergetic-based kinetic model has been employed to quantify metal bioavailability and accumulation in marine mussels (Wang et al. 1996 , 1997, Wang \& Fisher 1997). The model-predicted metal concentrations in mussel tissue were very close (within 2 to $3 x$ ) to tissue concentrations independently measured in national monitoring programs, suggesting that the biological and geochemical processes identified in the model can account for metal accumulation in mussels. In addition, with this model, which incorporates first-order physiological processes, it is possible to (1) diagnose processes critical to metal accumulation by performing sensitivity analyses and (2) separate the sources of metal accumulation in aquatic invertebrates (e.g. dissolved uptake vs particulate ingestion) (Wang \& Fisher 1997). Central to this model is the measurement of key physiological and geochemical parameters such as metal assimilation efficiency from ingested food particles (AE), metal uptake rate constant from the dissolved phase $\left(k_{\mathrm{u}}\right)$ and metal efflux rate constant $\left(k_{e}\right)$ from mussel tissues. While the influences of several abiotic and biotic factors on these physiological processes have been investigated (Wang \& Fisher 1997), there is little information concerning the effect of body size on each metal-specific physiological parameter described in the model.

The main objectives of this study were to measure the size-dependence of each metal-specific physiological parameter described in the bioenergetic-based bioaccumulation model, including $\mathrm{AE}, k_{\mathrm{u}}$ and $k_{\mathrm{e}}$. These physiological measurements were then incorporated into the kinetic model to predict the allometric relationship of metal concentration in mussels with body size. Sensitivity analysis was performed to determine the importance of factors influencing the allometry of metal accumulation. The significance of the growth rate constant in the kinetic model was emphasized. Finally, this model was used to separate the relative importance of uptake routes in different size classes of mussels, as such information is critical for setting appropriate water quality criteria.

\section{MATERIALS AND METHODS}

Mussels (Mytilus edulis) of 3 size classes $(1.5,2.5$, and $5.0 \mathrm{~cm}$ shell length, SL, or $0.05,0.15$ and $1.0 \mathrm{~g}$ tis- sue dry wt) were collected from Old Field, Long Island Sound, New York, USA, during September and October, 1996 and were acclimated in the laboratory in $10 \mathrm{l}$ at $15^{\circ} \mathrm{C}$ and $28 \%$ filtered seawater for about $1 \mathrm{wk}$ prior to experiments. All experiments were conducted at this temperature and salinity. During the acclimation period mussels were continuously fed with the diatom Thalassiosira pseudonana.

Assimilation efficiencies of trace elements in musseIs. The diatom Thalassiosira pseudonana (clone $3 \mathrm{H}$ ) was radiolabeled with the gamma-emitting radioisotopes ${ }^{109} \mathrm{Cd},{ }^{57} \mathrm{Co},{ }^{75} \mathrm{Se}$ and ${ }^{65} \mathrm{Zn}$, as described in Wang \& Fisher (1996a). Radioactivity additions were $148 \mathrm{kBq}$ $\mathrm{l}^{-1}$ (corresponding to $10 \mathrm{nM}$ ) for ${ }^{109} \mathrm{Cd}$ (in $0.5 \mathrm{~N} \mathrm{HCl}$ ), $11.1 \mathrm{kBq} \mathrm{l} l^{-1}$ (corresponding to $6.4 \mathrm{nM}$ ) for ${ }^{57} \mathrm{Co}$ (in $0.1 \mathrm{~N}$ $\mathrm{HCl}$ ), $74 \mathrm{kBq}^{-1}$ (corresponding to $0.9 \mathrm{nM}$ ) for ${ }^{75} \mathrm{Se}$ (in distilled water, $\mathrm{Na}_{2}{ }^{75} \mathrm{SeO}_{3}$ ), and $185 \mathrm{kBq} \mathrm{l}{ }^{-1}$ (corresponding to $30 \mathrm{nM}$ ) for ${ }^{65} \mathrm{Zn}$ (in $0.1 \mathrm{~N} \mathrm{HCl}$ ). After $4 \mathrm{~d}$ growth, the diatom cells had undergone 6 divisions and were considered to be uniformly labeled. These cells were then collected onto $3 \mu \mathrm{m}$ polycarbonate membranes and resuspended into $50 \mathrm{ml}$ filtered seawater before adding to the feeding beakers

Five individual mussels of 2.5 and $5.0 \mathrm{~cm}$ SL and 10 individual mussels of $1.5 \mathrm{~cm}$ SL were each placed into $800 \mathrm{ml}$ of $28 \%$ filtered seawater. Five batches of radiolabeled diatom cells were then added into each beaker at $5 \mathrm{~min}$ intervals, each giving a cell density of 4 to $5 \times 10^{4}$ cells $\mathrm{ml}^{-1}$. The amount ingested by each individual mussel corresponded to an ingestion rate of 0.3 to $0.5 \mathrm{mg} \mathrm{h}^{-1}$; at these ingestion rates, assimilation efficiencies are not affected by mussel ingestion activity (Wang et al. 1995). After 25 to $30 \mathrm{~min}$ of radioactive feeding, the mussels were rinsed with seawater and analyzed for their radioactivity. Fecal pellets were also collected and found to contain negligible radioactivity, suggesting that the radioactivity measured for whole individual mussels after the $20 \mathrm{~min}$ feeding represented the total amount of radioactivity ingested by the mussels. Individual mussels were then placed into separate polypropylene beakers $(150 \mathrm{ml}$ seawater) held within a $20 \mathrm{l}$ enclosed recirculating flow-through seawater aquarium, as described in Wang et al. (1995). Thalassiosira pseudonana was continuously dosed via a peristaltic pump into the aquarium. There were 5 replicate individuals for 2.5 and $5.0 \mathrm{~cm}$ mussels. For $1.5 \mathrm{~cm}$ mussels, 2 individual mussels were placed in each beaker and the radioactivity was measured as the composite of the 2 individuals ( 5 replicate composites). Radioactivity retained in the mussels was measured over a 4 d depuration period. Fecal pellets were collected frequently to minimize desorption of radiotracers from fecal material into the surrounding water. Assimilation efficiencies were determined as the percentage 
of initial radioactivity retained in the mussels after $72 \mathrm{~h}$ of depuration (mussels complete digestion and assimilation of trace elements within $72 \mathrm{~h}$; Wang et al. 1995).

Influx rates of trace elements from the dissolved phase. Detailed experimental procedures are described in Wang et al. (1996). Briefly, mussels which had been fed continuously with diatom cells were exposed to $0.5,2,5$, and $20 \mu \mathrm{g} \mathrm{l}^{-1}$ of $\mathrm{Cd}$ (in $\mathrm{CdCl}_{2}$ ), Co (in $\mathrm{CoCl}_{2}$ ), and $\mathrm{Se}$ (in $\mathrm{Na}_{2} \mathrm{SeO}_{3}$ ), and 2, 8, 20, and $100 \mu \mathrm{gl}^{-1}$ of $\mathrm{Zn}$ (in $\mathrm{ZnCl}_{2}$ ), respectively, for $1 \mathrm{~h}$ in $28 \%$ $0.2 \mu \mathrm{m}$-filtered seawater. Radioisotopes of ${ }^{109} \mathrm{Cd},{ }^{57} \mathrm{Co}$, ${ }^{75} \mathrm{Se}$ and ${ }^{65} \mathrm{Zn}$ were added into seawater as radiotracers; radioactivity additions were $4.6 \mathrm{kBq}^{-1}$ (corresponding to $0.3 \mathrm{nM}$ ) for ${ }^{109} \mathrm{Cd}, 9.2 \mathrm{kBq} \mathrm{l^{-1 }}$ (corresponding to $0.5 \mathrm{pM}$ ) for ${ }^{57} \mathrm{Co}, 13.8 \mathrm{kBq} \mathrm{l^{-1 }}$ (corresponding to $0.2 \mathrm{nM}$ ) for ${ }^{75} \mathrm{Se}$, and $9.2 \mathrm{kBq}^{-1}$ (corresponding to $1.5 \mathrm{nM}$ ) for ${ }^{65} \mathrm{Zn}$. There were 8 replicate individuals for 2.5 and $5.0 \mathrm{~cm} \mathrm{SL}$ mussels (4 pairs of 2 individuals, each pair in $500 \mathrm{ml}$ seawater) and 10 replicate individuals for $1.5 \mathrm{~cm}$ SL mussels (2 sets of 5 individuals, each set in $1 \mathrm{l}$ seawater). After $1 \mathrm{~h}$ exposure, mussels were dissected and radioactivities of soft tissues were measured. The loss of radioactivity in the dissolved phase due to uptake by mussels accounted for $<3 \%$ for $\mathrm{Cd}$, $<1 \%$ for $\mathrm{Co}$ and $\mathrm{Se}$, and $<7 \%$ for $\mathrm{Zn}$ of the initial radioactivity in the water. In addition, the short-term $(1 \mathrm{~h})$ exposure minimized the decline in mussel pumping activity due to the absence of food particles (Wang et al. 1996). The tissues were then dried at $70^{\circ} \mathrm{C}$ overnight and the dry weights were determined.

Efflux rates of trace elements from mussels. Two groups of mussels $(8$ individuals of $5.0 \mathrm{~cm} \mathrm{SL}$ and 8 individuals of $2.5 \mathrm{~cm}$ SL plus 13 individuals of $1.5 \mathrm{~cm}$ SL) were each placed in 1.51 filtered seawater and fed with radiolabeled Thalassiosira pseudonana cells for $7 \mathrm{~d}$ (the diatoms were radiolabeled as described above). Each day, log-phase cells were collected onto polycarbonate membranes and resuspended twice into unlabeled filtered seawater to remove metals (via desorption) bound weakly to cell surfaces, after which they were fed to the mussels for 4 to $6 \mathrm{~h}$. Radiolabeled diatoms were added at 0.5 to $1.0 \mathrm{~h}$ intervals into the feeding beakers. The mussels were then returned to the unlabeled seawater and fed with unlabeled diatom cells for another 18 to $20 \mathrm{~h}$. The water for both radiolabeling and non-radiolabeling feeding was replaced each day. After $7 \mathrm{~d}$ feeding, mussels were rinsed with filtered seawater and then measured for radioactivity. Three individuals from each size class were dissected to determine the distribution of radiotracers in the shell and soft tissues. The remaining 5 individuals (for 2.5 and $5.0 \mathrm{~cm}$ ) or 10 individuals (for $1.5 \mathrm{~cm}, 5$ replicate composites of 2 individuals each) were then placed into individual chambers within an enclosed recirculating aquarium, as described above and unlabeled diatom food ( $T$. pseudonana) was pumped continuously into the aquarium to provide a daily ration of about $2 \%$ of the mussel tissue dry wt (Wang et al. 1997). The dissected empty shells were depurated in the same recirculating system. Each day, the radioactivity remaining in the whole mussel was determined. Water was replaced every week to minimize the build-up of radioisotopes and metabolites in the water. After $28 \mathrm{~d}$ of depuration, mussels were dissected and the distribution of radiotracers in the shell and soft tissues was determined.

Clearance rates of mussels. To measure the clearance rates of mussels, 10 individuals of $1.5,2.5$, and $5.0 \mathrm{~cm} \mathrm{SL}$ were each placed into $2 \mathrm{l}$ (for $5.0 \mathrm{~cm}$ ) or $1.5 \mathrm{l}$ (for 1.5 and $2.5 \mathrm{~cm}$ ) filtered seawater within a polypropylene beaker. Five to 10 min after the mussels opened their shell valves and pumped normally, Thalassiosira pseudonana was added into each beaker at a concentration of $1.2 \times 10^{4}$ cells $\mathrm{ml}^{-1}$. These cells were collected from a log-phase culture and resuspended into $30 \mathrm{ml}$ filtered seawater (to remove algal metabolites and nutrients which may have affected the feeding activity of mussels; Ward \& Targett 1989). The algal suspension in each beaker was homogenized by a magnetic stirrer or by gentle aeration. Immediately after adding the algae and homogenization, an aliquot of $15 \mathrm{ml}$ water sample was taken and the cell density was counted using a Coulter Multisizer. Every $20 \mathrm{~min}$ (for $5.0 \mathrm{~cm}$ ) or $30 \mathrm{~min}$ (for 1.5 and $2.5 \mathrm{~cm}$ ), a $15 \mathrm{ml} \mathrm{sam}$ ple was taken and the cell density was determined. The clearance rate was measured over a 1 to $1.5 \mathrm{~h}$ period and then calculated using the following equation (Widdows et al. 1997):

$$
\mathrm{CR}=\mathrm{Vol} \times\left[\ln \left(C_{1}\right)-\ln \left(C_{2}\right)\right] / t
$$

where, CR is the clearance rate of mussels $\left(\mathrm{h} \mathrm{h}^{-1}\right), C_{1}$ is the cell density (cells $\mathrm{ml}^{-1}$ ) at time $1, C_{2}$ is the cell density (cells $\mathrm{ml}^{-1}$ ) at time 2, $t$ is the time interval of measurement $\left(t_{2}-t_{1}\right.$, in $\left.h\right)$, and $\mathrm{Vol}$ is the volume of water (l). The clearance rate of each individual was finally calculated from the mean of 3 consecutive measurements at 20 or 30 min intervals

Radioactivity measurements. Radioactivity of the whole mussel was measured non-invasively with a large-well NaI(Tl) gamma detector; radioactivity of water, labeled phytoplankton, the mussel's fecal pellets, and the mussel's soft tissues was determined with a Pharmacia-Wallac LKB NaI(Tl) gamma detector. All measurements were related to appropriate standards and calibrated with both spillover and radioactive decay. The gamma emission of ${ }^{109} \mathrm{Cd}$ was determined at $88 \mathrm{keV}$, of ${ }^{57} \mathrm{Co}$ at $122 \mathrm{keV}$, of ${ }^{75} \mathrm{Se}$ at $264 \mathrm{keV}$, and of ${ }^{65} \mathrm{Zn}$ at $1115 \mathrm{keV}$. Counting times in all samples were adjusted to yield propagated counting errors $<5 \%$. 
Kinetic modeling of allometry of trace element accumulation in mussels. According to the bioenergetic-based kinetic model, the metal concentration in mussels under steady-state conditions $\left(C_{s s}\right.$ in $\mu g$ $\mathrm{g}^{-1}$ ) can be described by the following equation (Wang et al. 1996):

$$
C_{\mathrm{ss}}=\frac{k_{\mathrm{u}} C_{\mathrm{w}}+\mathrm{AE} \times \mathrm{IR} \times C_{\mathrm{f}}}{k_{\mathrm{e}}+g}
$$

where $k_{\mathrm{u}}$ is the metal uptake rate constant from the dissolved phase $\left(\mathrm{l} \mathrm{g}^{-1} \mathrm{~d}^{-1}\right), C_{\mathrm{w}}$ is the dissolved metal concentration ( $\mu \mathrm{g} \mathrm{l}^{-1}$ ), $A E$ is the assimilation efficiency from ingested food particles, IR is the ingestion rate of the mussel $\left(\mathrm{g} \mathrm{g} \mathrm{g}^{-1} \mathrm{~d}^{-1}\right), C_{1}$ is the metal concentration in ingested food particles $(\mu \mathrm{g}$ $\left.\mathrm{g}^{-1}\right), k_{e}$ is the metal efflux rate constant $\left(d^{-1}\right)$, and $g$ is the growth rate constant of the mussel $\left(\mathrm{d}^{-1}\right)$.

If $C_{f}$ is not known, it can be calculated from:

$$
C_{\mathrm{f}}=K d \times C_{\mathrm{w}}
$$

where $K d$ is the partition coefficient $\left(\mathrm{l} \mathrm{g}^{-1}\right)$ of the metal for suspended particles. Thus Eq. (3) can be rewritten as:

$$
C_{\mathrm{ss}}=\frac{\left(k_{\mathrm{u}}+\mathrm{AE} \times \operatorname{IR} \times C_{\mathrm{f}}\right) \times C_{\mathrm{w}}}{k_{\mathrm{e}}+g}
$$

or

$$
B C F=\frac{C_{\text {ss }}}{C_{w}}=\frac{\left(k_{u}+\mathrm{AE} \times \operatorname{IR} \times K d\right)}{k_{\mathrm{e}}+g}
$$

where $C_{s s} / C_{w}$ is defined here as the bioconcentration factor (BCF), and is directly related to the metal concentration in the mussel. The coefficient of metal allometry (b) can then be calculated assuming that $\mathrm{BCF}$ is a power function of mussel tissue dry weight $(W)$ :

$$
\mathrm{BCF}=\mathrm{a} W^{\mathrm{b}}
$$

or

$$
\log (\mathrm{BCF})=\log (\mathrm{a})+\mathrm{b} \log (W)
$$

from which b can be calculated as the slope of the log$\log$ relationship between $\mathrm{BCF}$ and $W$. This equation is comparable to the power equation relating metal concentration with body size (Boyden 1974, 1977). A b value $>0$ indicates that metal accumulation (or metal concentration in mussels) increases with growth and a $b$ value $<0$ indicates that metal accumulation decreases with a mussel's growth. When the b value is close to 0 , metal accumulation is relatively independent of a mussel's growth.

\section{RESULTS}

\section{Assimilation efficiencies of trace elements in mussels from ingested diatoms}

Depuration patterns of radiotracers in mussels during the $96 \mathrm{~h}$ depuration period are shown in Fig. 1. Generally, depuration was characterized by a rapid loss within the first day, and then a slower loss between 24 and $96 \mathrm{~h}$. There was very little loss of Cd during the second phase of digestion ( 24 to $72 \mathrm{~h}$ ), whereas notable loss was observed for $\mathrm{Co}$. Se and $\mathrm{Zn}$ were intermediate between $\mathrm{Cd}$ and $\mathrm{Co}$ in their depuration during the second phase of digestion (Table 1).

AEs for Se and Zn did not differ significantly among the 3 body sizes (Table 1). AEs for Cd were significantly lower in $5.0 \mathrm{~cm}$ mussels than in smaller mussels but for Co AEs increased with body size. Differences in Cd assimilation among the 3 body sizes were mainly attributable to variations in the first phase of digestion (within the first day), whereas differences in Co assimilation were attributable to variations in the second phase of digestion ( 1 to $3 \mathrm{~d}$ ). The calculated depuration rate constant during the second phase was $2 \times$ lower in $5.0 \mathrm{~cm}$ mussels than in smaller mussels. A similar trend of metal assimilation was also observed in mussels feeding on the diatom Phaeodactylum tricornutum in which Cd assim- 
Table 1. Mytilus edulis. Assimilation efficiencies (AE) of trace elements in different size classes of mussels feeding on the diatom Thalassiosira pseudonana. The depuration rate constant $\left(k_{2}\right)$ during the second phase of digestion $(24$ to $72 \mathrm{~h})$ is also presented. $k_{2}$ is calculated from the regression: $A=\mathrm{a} \times \exp \left(-k_{2} \times t\right)$, where $A$ is the percentage of radioactivity retained in mussels at time $t$. Values are means $\pm 1 \mathrm{SD}(\mathrm{n}=5) .{ }^{\mathrm{A}}$ and ${ }^{B}$ indicate that there is a statistically significant difference $(\mathrm{p}<0.05)$ in $\mathrm{AE}$ or $k_{2}$ between 2 corresponding mussel size treatments

\begin{tabular}{|c|c|c|c|c|c|c|}
\hline & $1.5 \mathrm{~cm}$ & $\begin{array}{l}A E(\%) \\
2.5 \mathrm{~cm}\end{array}$ & $5.0 \mathrm{~cm}$ & $1.5 \mathrm{~cm}$ & $\begin{array}{l}k_{2}\left(\mathrm{~d}^{-1}\right) \\
2.5 \mathrm{~cm}\end{array}$ & $5.0 \mathrm{~cm}$ \\
\hline $\mathrm{Cd}$ & $31 \pm 4^{A}$ & $33 \pm 8$ & $21 \pm 6^{A}$ & $0.055 \pm 0.047$ & $0.076 \pm 0.048$ & $0.038 \pm 0.023$ \\
\hline $\mathrm{Co}$ & $24 \pm 6^{A}$ & $29 \pm 6$ & $36 \pm 4^{A}$ & $0.446 \pm 0.041^{\mathrm{A}}$ & $0.441 \pm 0.085^{\mathrm{B}}$ & $0.220 \pm 0.088^{\mathrm{A}, \mathrm{B}}$ \\
\hline $\mathrm{Se}$ & $81 \pm 5$ & $82 \pm 6$ & $72 \pm 11$ & $0.075 \pm 0.014^{4}$ & $0.070 \pm 0.007^{8}$ & $0.048 \pm 0.009^{A, B}$ \\
\hline $\mathrm{Zn}$ & $20 \pm 7$ & $24 \pm 3$ & $26 \pm 2$ & $0.189 \pm 0.065$ & $0.136 \pm 0.030$ & $0.118 \pm 0.008$ \\
\hline
\end{tabular}

ilation decreased and Co assimilation increased with increasing mussel body size (data not shown).

\section{Influx rates of trace elements from the dissolved phase}

The influx rates of metals from the dissolved phase in mussels at different ambient dissolved concentrations are shown in Fig. 2. There was a log-log linear relationship between the influx rate and the dissolved metal concentration (Table 2). The coefficient of this relationship was close to 1 , suggesting that dissolved uptake of metals in mussels was dominated by passive

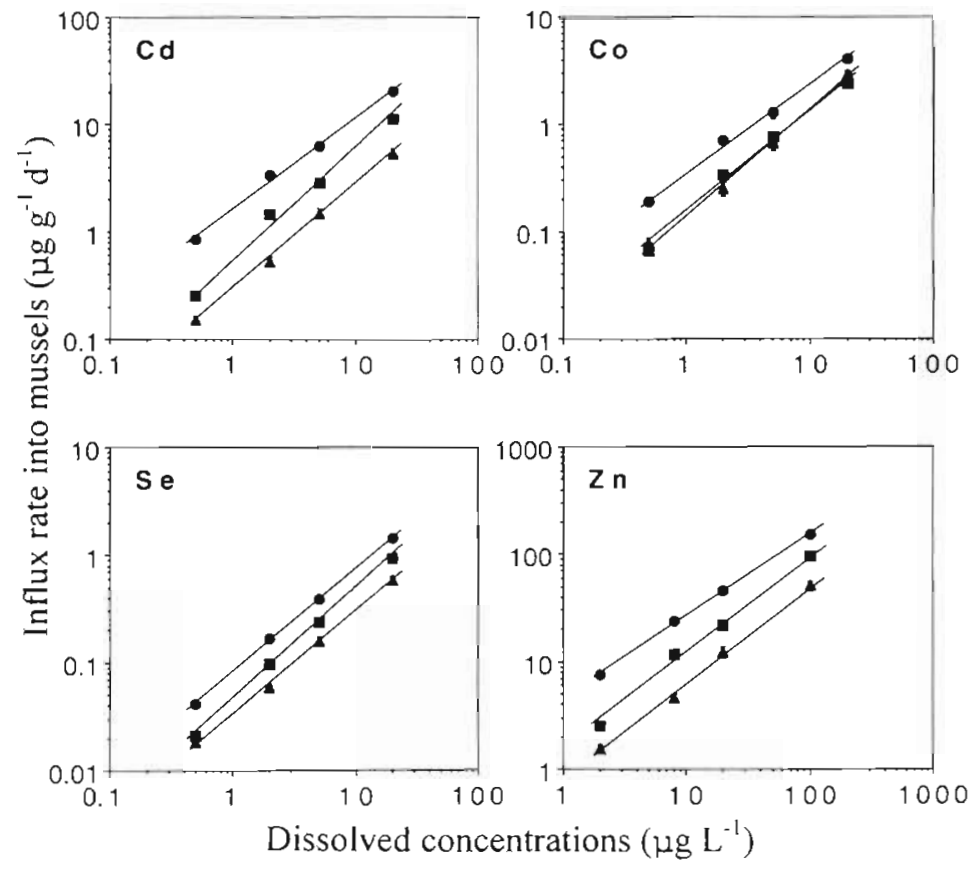

Fig. 2. Mytilus edulis. Influx rates of trace elements from the dissolved phase into mussels at different ambient metal concentrations. Values are means $\pm 1 \mathrm{SD}(\mathrm{n}=8)_{\text {i }}$ in most cases $\mathrm{SD}$ was smaller than the symbols

(•) $1.5 \mathrm{~cm}$ mussels, (-) $2.5 \mathrm{~cm}$ mussels, (4) $5.0 \mathrm{~cm}$ mussels and/or facilitated diffusion. For $1.5 \mathrm{~cm}$ mussels, the coefficient was $<1$, being smallest for $\mathrm{Zn}$, indicating that these juvenile mussels might be able to slightly regulate their metal uptake from the dissolved phase. The dissolved uptake rate constants $\left(k_{u}\right)$, calculated from the intercept of the $\log$-log relationship between metal influx rate and dissolved metal concentration (assuming that the coefficient of this relationship was 1), are shown in Table 2. Values of $k_{\mathrm{u}}$ were highest for $\mathrm{Zn}$, followed by $\mathrm{Cd}>\mathrm{Co}>\mathrm{Se}$. $k_{\mathrm{u}}$ increased with decreasing body size (Fig. 3). The coefficient describing the power function between metal $k_{\mathrm{u}}$ and tissue dry weight was -0.56 for $\mathrm{Cd},-0.30$ for $\mathrm{Co},-0.29$ for $\mathrm{Se}$, and -0.57 for $\mathrm{Zn}$. Thus, the uptake of dissolved $\mathrm{Cd}$ and $\mathrm{Zn}$ was most affected by body size. The absorption efficiency $\left(\alpha_{w}\right)$ was also calculated from the $k_{\mathrm{u}}$ divided by the clearance rate (CR) of mussels (see below) (Table 2). Although notable differences in $k_{\mathrm{u}}$ were measured among the 3 body sizes, $\alpha_{w}$ generally did not vary greatly with size, the greatest variation being 2 - to 3-fold for Co and Se. Given the high variation of $C R$ measured for 2.5 and $5.0 \mathrm{~cm}$ mussels, it could be concluded that the $\alpha_{w}$ for these metals were relatively independent of body size or slightly higher in larger mussels. $\alpha_{w}$ was highest for $Z_{n}$, followed by $\mathrm{Cd}>\mathrm{Co}>\mathrm{Se}$.

\section{Efflux rates of trace elements from mussels}

Depuration of metals following $7 \mathrm{~d}$ feeding on radiolabeled diatoms generally did not follow a single exponential decay (Fig. 4). Efflux rate constants were calculated (Table 3) from metal depuration curves between 7 and $28 \mathrm{~d}$ to minimize possible interference from metal lost due to digestive processes. The calculated efflux rate constants for all metals ranged between 0.01 
Table 2. Mytilus edulis. Relationships between metal influx rate from the dissolved phase $\left(I_{u}\right)$ and dissolved metal concentration $\left(C_{w}\right)$. Also shown are the estimated dissolved uptake rate constant $\left(k_{u}\right)$ and absorption efficiency from the dissolved phase $\left(\alpha_{w}\right)$ in different size mussels

\begin{tabular}{|c|c|c|c|c|c|c|}
\hline & Size & Equation & $r^{2}$ & $k_{\mathrm{u}}\left(\mathrm{lg}^{-1} \mathrm{~d}^{-1}\right)$ & $k_{\mathrm{u}}$ range $\left(\mathrm{l} \mathrm{g}^{-1} \mathrm{~d}^{-1}\right)$ & $a_{n v}(\%)$ \\
\hline $\mathrm{Cd}$ & $\begin{array}{l}1.5 \mathrm{~cm} \\
2.5 \mathrm{~cm} \\
5.0 \mathrm{~cm}\end{array}$ & $\begin{array}{l}l_{u}=1.648\left[C_{w}\right]^{0.850 \pm 0.041} \\
I_{u}=0.578\left[C_{w^{\prime}}\right]^{1.013 \pm 0.071} \\
I_{u}=0.289\left[C_{w}\right]^{0.981}=0.0124\end{array}$ & $\begin{array}{l}0.995 \\
0.990 \\
0.999\end{array}$ & $\begin{array}{l}1.648 \\
0.578 \\
0.289\end{array}$ & $\begin{array}{l}1.475-1.842 \\
0.477-0.700 \\
0.271-0.308\end{array}$ & $\begin{array}{l}0.287 \\
0.184 \\
0.352\end{array}$ \\
\hline $\mathrm{Co}$ & $\begin{array}{l}1.5 \mathrm{~cm} \\
2.5 \mathrm{~cm} \\
5.0 \mathrm{~cm}\end{array}$ & $\begin{array}{l}I_{\mathrm{u}}=0.355\left[C_{\mathrm{w}}\right]^{0.823 \pm 0.037} \\
I_{\mathrm{u}}=0.148\left[C_{\mathrm{w}}\right]^{0.972 \pm 0.066} \\
I_{\mathrm{u}}=0.142\left[C_{\mathrm{w}}\right]^{0.989 \pm 0.042}\end{array}$ & $\begin{array}{l}0.996 \\
0.991 \\
0.996\end{array}$ & $\begin{array}{l}0.355 \\
0.148 \\
0.142\end{array}$ & $\begin{array}{l}0.321-0.392 \\
0.124-0.176 \\
0.126-0.159\end{array}$ & $\begin{array}{l}0.062 \\
0.047 \\
0.172\end{array}$ \\
\hline Se & $\begin{array}{l}1.5 \mathrm{~cm} \\
2.5 \mathrm{~cm} \\
5.0 \mathrm{~cm}\end{array}$ & $\begin{array}{l}I_{\mathrm{u}}=0.082\left[C_{\mathrm{w}}\right]^{0.963 * 0.013} \\
I_{\mathrm{u}}=0.044\left[C_{\mathrm{w}}\right]^{1.027}=0.020 \\
I_{\mathrm{u}}=0.033\left[C_{\mathrm{w}}\right]^{0.960 * 0.027}\end{array}$ & $\begin{array}{l}0.999 \\
0.999 \\
0.996\end{array}$ & $\begin{array}{l}0.082 \\
0.044 \\
0.033\end{array}$ & $\begin{array}{l}0.080-0.085 \\
0.042-0.047 \\
0.030-0.035\end{array}$ & $\begin{array}{l}0.014 \\
0.014 \\
0.040\end{array}$ \\
\hline $\mathrm{Zn}$ & $\begin{array}{l}1.5 \mathrm{~cm} \\
2.5 \mathrm{~cm} \\
5.0 \mathrm{~cm}\end{array}$ & $\begin{array}{l}l_{\mathrm{u}}=4.639\left[C_{\mathrm{w}}\right]^{0.765 * 0.015} \\
I_{\mathrm{u}}=1.464\left[C_{\mathrm{w}}\right]^{0.916 \pm 0.048} \\
I_{\mathrm{u}}=0.788\left[C_{\mathrm{w}}\right]^{0.904 \pm 0.031}\end{array}$ & $\begin{array}{l}0.999 \\
0.994 \\
0.998\end{array}$ & $\begin{array}{l}4.639 \\
1.464 \\
0.788\end{array}$ & $\begin{array}{l}4.449-4.639 \\
1.276-1.681 \\
0.722-0.860\end{array}$ & $\begin{array}{l}0.808 \\
0.467 \\
0.960\end{array}$ \\
\hline
\end{tabular}

and $0.03 \mathrm{~d}^{-1}$. No statistically significant difference was detected for $\mathrm{Co}$, Se, and $\mathrm{Zn}$ among the 3 body sizes ( $\mathrm{p}>$ 0.05). Cd was lost at a significantly slower rate $(2 \times$ less) from $5.0 \mathrm{~cm}$ mussels than from $1.5 \mathrm{~cm}$ or $2.5 \mathrm{~cm}$ mussels $(p<0.01)$. The percentage of metals in the slowest exchanging compartment for $\mathrm{Cd}$, Se and $\mathrm{Zn}$ was comparable among 3 size classes, but was higher for Co in
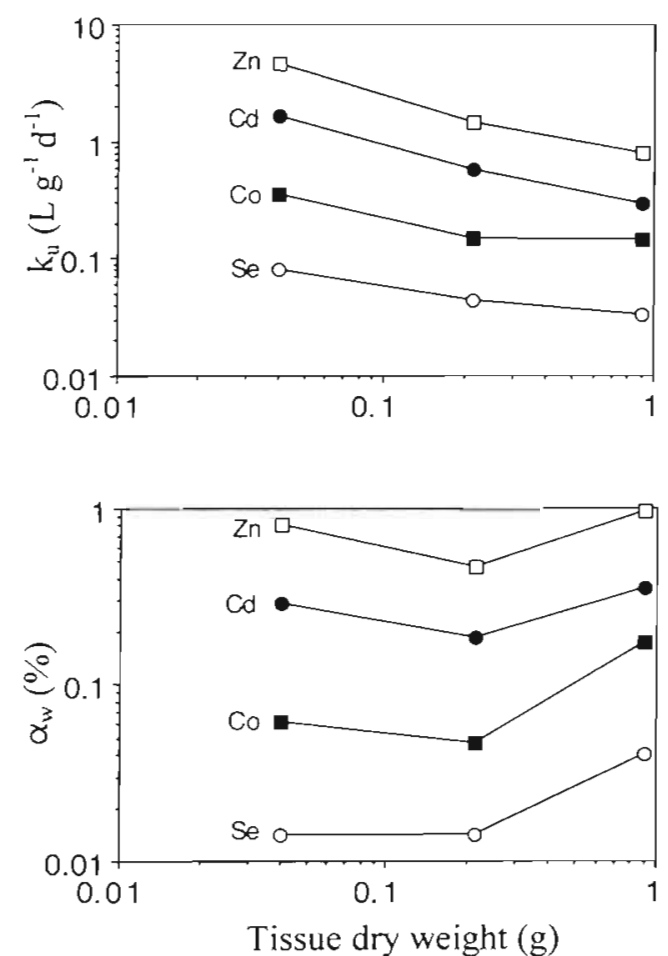

Fig. 3. Mytilus edulis. Relationships of estimated uptake rate constants $\left(k_{u}\right)$ and absorption efficiencies $\left(\alpha_{w}\right)$ of trace elements from the dissolved phase with the tissue dry weight of mussels
Table 3. Mytilus edulis. Efflux rate constants of trace elements $\left(k_{e}\right)$ in different size classes of mussels. Efflux rate constants were calculated from the slowest exchanging compartments ( 7 iu 28 di), using the equation: $\dot{A}=\mathrm{a} \times \exp \left(-k_{\mathrm{e}} \times t\right)$, where $A$ is the percentage of radioactivity retained in mussels at time $t$. The retention half-times $\left(t b_{1 / 2}\right)$ of metals and the percentage of metals in the slowest exchanging compartment are also shown (values are means $\pm 1 \mathrm{SD}, \mathrm{n}=5$ ). ${ }^{\mathrm{A}}$ and ${ }^{8}$ indicate that there was a statistically significant difference $(p<0.05)$ between 2 treatments (mussel size). Depuration rate constants and retention half-times of metals in dissected shells are also shown (values are means $\pm 1 \mathrm{SD}, \mathrm{n}=2$ for $2.5 \mathrm{~cm}$ shell, $\mathrm{n}=1$ for $5.0 \mathrm{~cm}$ shell). nd: not determined

\begin{tabular}{|c|c|c|c|}
\hline & $1.5 \mathrm{~cm}$ & $2.5 \mathrm{~cm}$ & $5.0 \mathrm{~cm}$ \\
\hline \multicolumn{4}{|c|}{ Efflux from whole mussels } \\
\hline \multicolumn{4}{|c|}{$k_{\mathrm{e}}\left(\mathrm{d}^{-1}\right)$} \\
\hline $\mathrm{Cd}$ & $0.0345 \pm 0.0076^{A}$ & $0.0324 \pm 0.0046^{\mathrm{B}}$ & $0.0167 \pm 0.0022^{\mathrm{A} . \mathrm{B}}$ \\
\hline Co & $0.0331 \pm 0.0071$ & $0.0326 \pm 0.0029$ & $0.0271 \pm 0.0081$ \\
\hline $\mathrm{Se}$ & $0.0216 \pm 0.0009$ & $0.0200 \pm 0.0028$ & $0.0180 \pm 0.0020$ \\
\hline $\mathrm{Zn}$ & $0.0123 \pm 0.0023$ & $0.0141 \pm 0.0031$ & $0.0141 \pm 0.0030$ \\
\hline \multicolumn{4}{|c|}{$t b_{1 / 2}(\mathrm{~d})$} \\
\hline $\mathrm{Cd}$ & $21.4 \pm 6.0^{\mathrm{A}}$ & $21.8 \pm 2.9^{\mathrm{B}}$ & $42.2 \pm 5.2^{\mathrm{A.B}}$ \\
\hline $\mathrm{Co}$ & $22.1 \pm 5.7$ & $21.4 \pm 1.9$ & $27.3 \pm 5.9$ \\
\hline $\mathrm{Se}$ & $32.1 \pm 1.3$ & $35.3 \pm 5.3$ & $38.8 \pm 4.2$ \\
\hline $\mathrm{Zn}$ & $58.5 \pm 12.3$ & $51.3 \pm 10.6$ & $52.0 \pm 13.0$ \\
\hline \multicolumn{4}{|c|}{$\%$ in slowest exchanging compartment } \\
\hline $\mathrm{Cd}$ & $83.3 \pm 10.6$ & $90.1 \pm 9.3$ & $84.4 \pm 6.8$ \\
\hline $\mathrm{Co}$ & $17.4 \pm 5.3^{\mathrm{A}}$ & $19.1 \pm 2.6^{\mathrm{B}}$ & $41.9 \pm 11.8^{A, B}$ \\
\hline $\mathrm{Se}$ & $74.3 \pm 1.5$ & $74.2 \pm 4.4$ & $83.4 \pm 3.7$ \\
\hline $\mathrm{Zn}$ & $51.1 \pm 2.5$ & $55.9 \pm 4.8$ & $58.9 \pm 6.4$ \\
\hline \multicolumn{4}{|c|}{ Depuration from dissected shells } \\
\hline \multicolumn{4}{|c|}{$k_{\mathrm{e}}\left(\mathrm{d}^{-1}\right)$} \\
\hline $\mathrm{Co}$ & nd & $0.0070 \pm 0.0003$ & 0.0049 \\
\hline $\mathrm{Se}$ & nd & $0.0094 \pm 0.0005$ & 0 \\
\hline $\mathrm{Zn}$ & nd & $0.0171 \pm 0.0033$ & 0.0158 \\
\hline \multicolumn{4}{|c|}{$t b_{1 / 2}(\mathrm{~d})$} \\
\hline Co & nd & $99.4 \pm 4.7$ & 142.0 \\
\hline $\mathrm{Se}$ & nd & $73.6 \pm 3.6$ & $\infty$ \\
\hline $\mathrm{Zn}$ & nd & $42.2 \pm 8.3$ & 43.9 \\
\hline
\end{tabular}



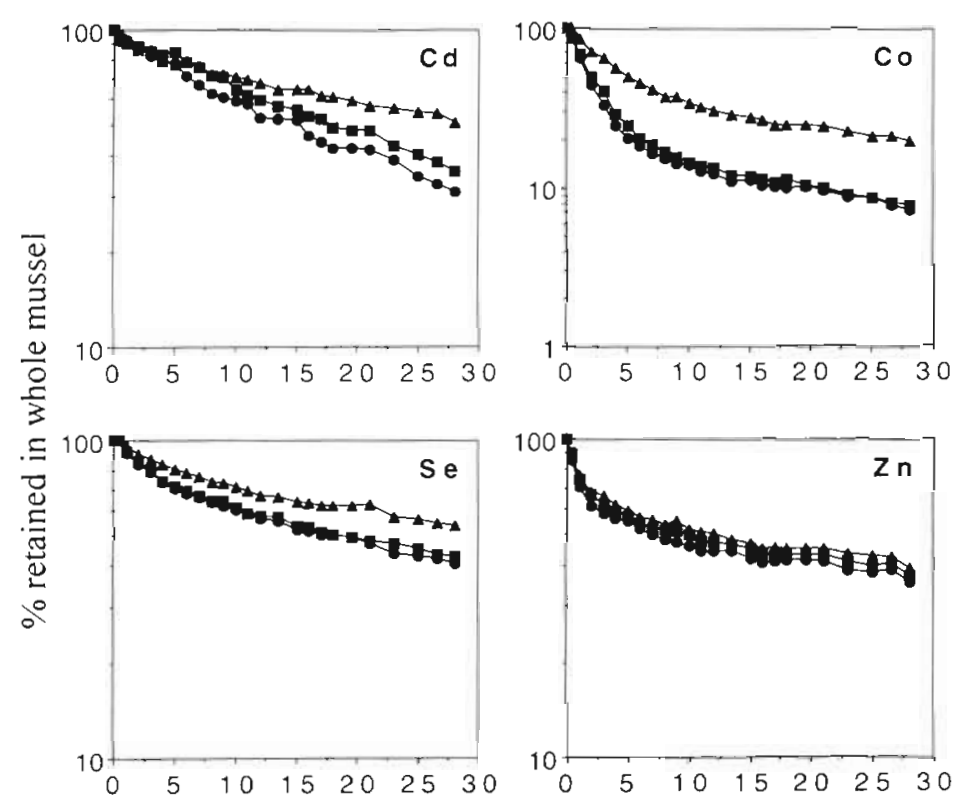

Days

Fig. 4. Mytilus edulis. Depuration of radiotracers in whole mussels (soft tissues plus shell) over $28 \mathrm{~d}$ following $7 \mathrm{~d}$ ingestion of the radiolabeled diatom Thalassiosira pseudonana. Values are means $(\mathrm{n}=5) .(\bullet 1.5 \mathrm{~cm}$ mussels, (a) $2.5 \mathrm{~cm}$ mussels, (4) $5.0 \mathrm{~cm}$ mussels
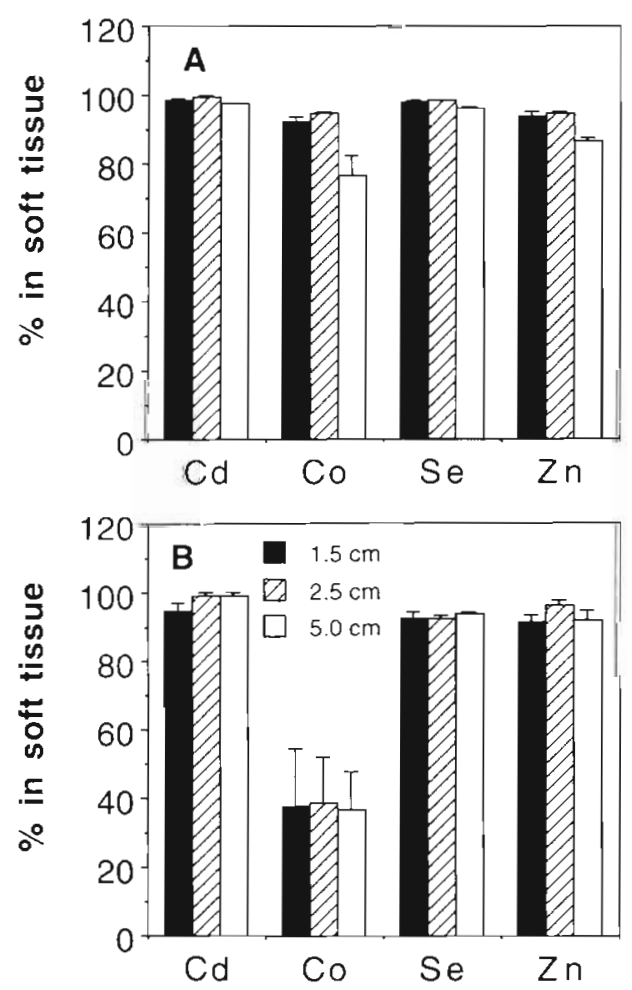

Fig. 5. Mytilus edulis. Distribution of radiotracers in the soft tissues of mussels (A) after $7 d$ ingestion of the radiolabeled diatom Thalassiosira pseudonana, means $+1 \mathrm{SD}(\mathrm{n}=3)$, and

(B) after $28 \mathrm{~d}$ depuration, means $+1 \mathrm{SD}(\mathrm{n}=5)$
$5.0 \mathrm{~cm}$ mussels than in smaller mussels $(\mathrm{p}<$ 0.01 ), consistent with the AE measurements described above. During the 4 wk depuration period, shell length of the 1.5 and $2.5 \mathrm{~cm}$ groups of mussels increased by $0.28 \pm 0.07 \mathrm{~cm}$ $(\mathrm{n}=10)$ and $0.26 \pm 0.07 \mathrm{~cm}(\mathrm{n}=5)$, respectively. Because there was very little difference in the efflux rate constants between these 2 body sizes for all of the trace elements, the variation in metal efflux rate as a result of mussel growth should have little effect on our calculations (see below).

Following $7 \mathrm{~d}$ ingestion of radiolabeled diatoms, most metals were distributed in the mussels' soft tissues, while the shells only contained a small fraction $[<7 \%$, except for Co $(23 \%)$ and $\mathrm{Zn}(13 \%)$ in the largest mussels] of total radioactivity ingested by the mussels (Fig. 5). Consequently, efflux rate constants of metals measured for whole mussels (shell plus soft tissues) probably represented the efflux of metals from soft tissues. By the end of $28 \mathrm{~d}$ of depuration, most of the Cd, Se and Zn (>92\%) was still in the soft tissues, whereas only $40 \%$ of Co was in the soft tissues in all 3 body sizes. The loss of metals from dissected shells was characterized by a 1 -compartmental $(\mathrm{Co}, \mathrm{Se})$ or 2-compartmental $(\mathrm{Zn})$ depuration (data not shown). Depuration of $\mathrm{Cd}$ from dissected shells was not determined due to very little $\mathrm{Cd}$ associated with the shells. Depuration rate constants calculated between 7 and $28 \mathrm{~d}$ were much lower (except for $\mathrm{Zn}$ ) than the efflux rate constant determined for whole mussels, especially for $5.0 \mathrm{~cm}$ mussels (Table 3 ).

\section{Clearance rates of mussels}

The clearance rates of mussels $\left(\mathrm{l} \mathrm{h}^{-1}\right)$ increased with body size, from $1.28 \mathrm{l} \mathrm{h}^{-1}$ in $1.5 \mathrm{~cm}$ mussels to $4.18 \mathrm{l} \mathrm{h}^{-1}$ in $5.0 \mathrm{~cm}$ mussels (Fig. 6). However, the weightspecific clearance rate decreased with body size, from $23.93 \mathrm{l} \mathrm{g}^{-1} \mathrm{~h}^{-1}$ in $1.5 \mathrm{~cm}$ mussels to $3.42 \mathrm{l} \mathrm{g}^{-1} \mathrm{~h}^{-1}$ in $5.0 \mathrm{~cm}$ mussels. The power relationship between weight-specific clearance rate and tissue dry weight (g) can be described as:

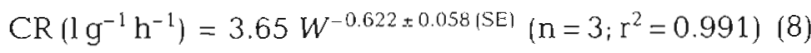

\section{Kinetic modeling of allometry of trace element accumulation in mussels}

Three size classes of mussels $(1.5,2.5$, and $5.0 \mathrm{~cm} \mathrm{SL}$, or $0.05,0.15$, and $1.0 \mathrm{~g}$ tissue dry wt) were included in 


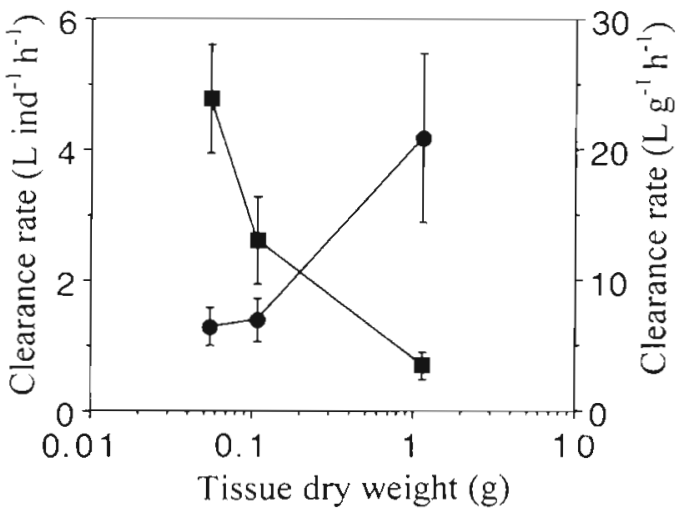

Fig. 6. Mytilus edulis. Individual ( ) and weight-specific ( clearance rates of different sizes of mussels. Values are means $\pm 1 \mathrm{SD}(\mathrm{n}=10)$

our modeling analysis. Values of $k_{\mathrm{u}}$ AE, and $k_{\mathrm{e}}$ for each size class were taken from this study (Tables $1-$ 3). The mussel's IR was calculated by:

$$
\mathrm{IR}=\mathrm{CR} \times \mathrm{TSS}
$$

where TSS is the total suspended solid load $\left(\mathrm{mg} \mathrm{l}^{-1}\right)$ This calculation assumed that mussels had a 100\% retention efficiency of particles $>3 \mu \mathrm{m}$ (Bayne \& Newell 1983) and that mussel ingestion rate has a linear relationship with food concentration. However, at higher TSS loads, mussels can produce pseudofeces and maintain a maximum ingestion rate. The TSS loads at which mussels produce pseudofeces can vary with body size. The threshold concentration increases from about $2.5 \mathrm{mg} \mathrm{l}^{-1}$ in juvenile mussels ( $1.7 \mathrm{~cm} \mathrm{SL}$ ) to $4.5 \mathrm{mg} \mathrm{l}^{-1}$ in large mussels $(5 \mathrm{~cm}$ SL) (Widdows et al. 1979). Assuming that TSS loads in estuarine waters are $>5$ to $6 \mathrm{mg} \mathrm{l}^{-1}$, the maximum ingestion activity can be calculated from Eq. (9) as $1.44 \mathrm{~g} \mathrm{~g}^{-1} \mathrm{~d}^{-1}$ for $1.5 \mathrm{~cm}$ mussels, $0.94 \mathrm{~g} \mathrm{~g}^{-1} \mathrm{~d}^{-1}$ for $2.5 \mathrm{~cm}$ mussels (with a threshold concentration of TSS for pseudofeces production of $3 \mathrm{mg} \mathrm{l}^{-1}$ ), and $0.37 \mathrm{~g} \mathrm{~g}^{-1} \mathrm{~d}^{-1}$ for $5.0 \mathrm{~cm}$ mussels. To make our modeling applicable to natural waters which contain diverse particle assemblages, we have used mean $K d\left(\mathrm{~kg}^{-1}\right)$ values for each trace element for suspended marine particles (5000 for Cd, 5000 for Co, 10000 for Se and 20000 for $Z n$; see discussion in Wang et al. 1996).

There are great uncertainties of the growth rate constant $(g)$ in marine mussels, which can vary greatly with environmental conditions (location, food composition, food quantity, temperature, season; Seed \& Richardson 1990). Recently, Clausen \& Riisgărd (1996) determined a maximum $g$ of $8.0 \% \mathrm{~d}^{-1}$ in mussels transferred in net bags to a fjord system. Generally $g$ is within 1 to $10 \% \mathrm{~d}^{-1}$ in various ecosystems (Jørgensen 1996). In our calculations, we set $g$ for the $1.5 \mathrm{~cm}$ mussels and then calculated $g$ for the 2 larger sizes

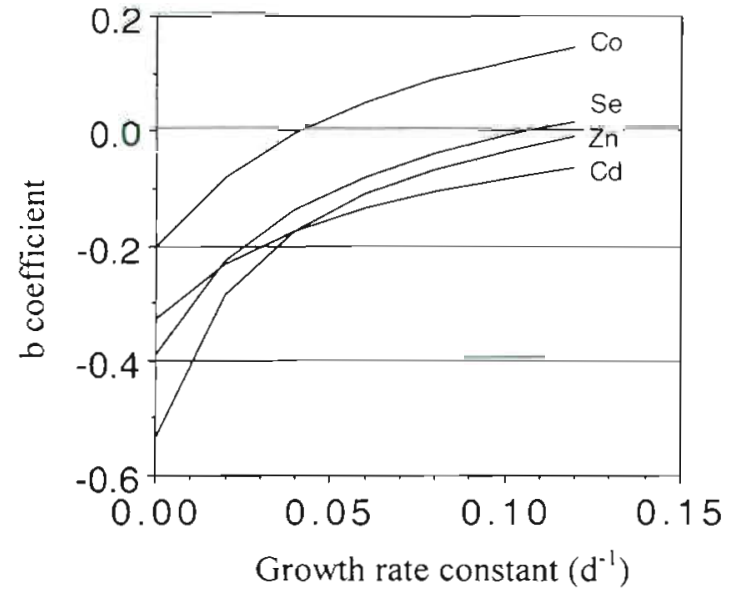

Fig. 7. Mytilus edulis. Predicted b values (power function of metal accumulation with body size) of trace elements as a function of the growth rate constant $(g)$ of a juvenile mussel of $50 \mathrm{mg}$ dry wt. See text for mathematical treatment of the calculation

of mussels assuming that it scaled with body size (following a power function) with a coefficient of 0.67 (Bayne \& Worrall 1980), thus $g$ values for $2.5 \mathrm{~cm}$ and $5.0 \mathrm{~cm}$ mussels can be calculated accordingly. This is probably the simplest approach in modeling $g$ in mussels. A range of $g$ values for $1.5 \mathrm{~cm}$ mussels 10 to $0.12 \mathrm{~d}^{-1}$ ) was therefore used to initialize our modeling analysis. The BCF for each body size of mussel was calculated using Eq. (5) (using different $g$ values for each body size) and the allometric coefficient (b) was calculated using Eq. (7).

Fig. 7 shows the calculated b values as a function of $g$ in $1.5 \mathrm{~cm}$ mussels. Clearly, allometry of metal accumulation in mussels is sharply influenced by $g$. Such allometry ranges from positive (e.g. Co at higher $g$ ) to negative relationships (e.g. $\mathrm{Cd}, \mathrm{Se}$, and $\mathrm{Zn}$ ). Under most circumstances the model predicts that metal concentrations in mussels decrease with increasing body size or are relatively constant throughout the size range investigated in this study $(0.05$ to $1.0 \mathrm{~g}$ dry wt). An increase in $g$ in juvenile mussels results in an exponential increase in the $b$ value. With a decrease in $g$ (such as brought on by limited food conditions or winter), b values become more conspicuously negative indicating that metal concentrations in mussels are more dependent on body size. When $g$ is not incorporated into the model $(g=0)$, the b values decrease sharply and become -0.33 for $\mathrm{Cd},-0.20$ for $\mathrm{Co},-0.40$ for $\mathrm{Se}$, and -0.54 for $\mathrm{Zn}$, respectively. These values are much lower than the empirical measurements in mussels collected from the field (e.g. -0.1 for $\mathrm{Cd}_{1}-0.1$ to -0.2 for $\mathrm{Zn}$; Boyden 1977), indicating that $g$ must be included in the kinetic model to predict the allometry of metal accumulation. 

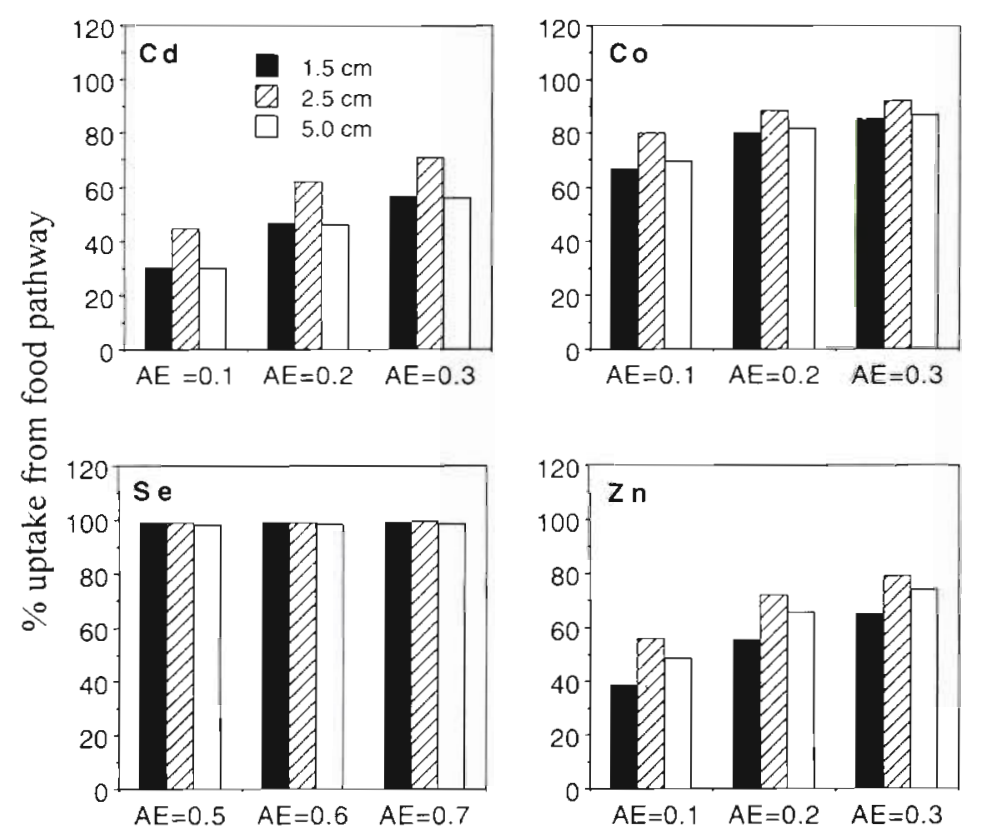

Estimations of the ratio $R$ at different AEs for each trace element are shown in Fig. 8. Clearly, the relative importance of dissolved versus food ingestion in metal uptake is relatively unaffected by mussel body size; for $\mathrm{Zn}$ there is a slight increase in the percentage of uptake from food in $5.0 \mathrm{~cm}$ mussels. Under the conditions employed in this study, most Se $(98 \%)$ is predicted to accumulate from the food ingestion pathway. Uptake from food accounts for 30 to $75 \%$ of $\mathrm{Cd}, 67$ to $92 \%$ of

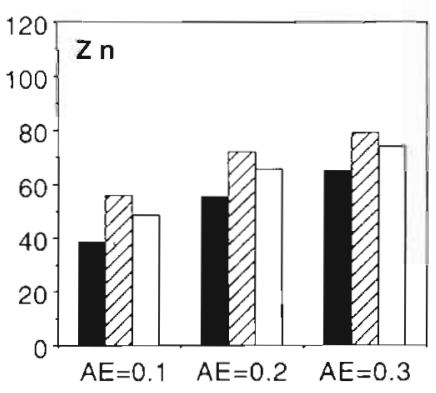
$\mathrm{Co}$, and 40 to $84 \%$ of $\mathrm{Zn}$ in mussels. The relative importance of a metal's uptake from the dissolved phase is inversely related to its AE.

\section{DISCUSSION}

\section{Kinetic modeling of allometry of metal accumulation in mussels}

Fig. 8. Mytilus edulis. Predicted percentage uptake of trace elements from the food source into different size mussels over a range of metal assimilation efficiencies (AE)

Our model suggests that the growth rate constant should be incorporated into kinetic models to evaluate the effects of body size on metal accumulation in mussels. When $g$ is

\section{Kinetic separation of the uptake routes of trace elements in mussels}

The percentage of trace element uptake from food (R) can be calculated from Eq. (5):

$$
R=(\mathrm{AE} \times \mathrm{IR} \times K d) /\left[\left(k_{\mathrm{u}}\right)+(\mathrm{AE} \times \mathrm{IR} \times K d)\right]
$$
not considered, the predicted allometric coefficients are significantly lower than $b$ values determined with field samples of varying sizes (Table 4). Previously (Wang et al. 1996), $g$ was ignored in a kinetic model describing metal accumulation in adult Mytilus edulis, and the predicted metal concentrations in the mussels were within 2 to 3 times the actual metal concentra-

Table 4. Mytilus edulis. Empirical measurements of $\mathrm{b}$ values of the power relationship between metal concentration and tissue dry weight in marine mussels from different locations

\begin{tabular}{|c|c|c|c|c|}
\hline Metal & Location & Tissue dry wt (g) & $\mathrm{b}$ & Source \\
\hline \multirow[t]{6}{*}{$\mathrm{Cd}$} & Poole Harbour, UK & $0.26-1.94$ & -0.03 & Boyden (1977) \\
\hline & Cornwall, UK & $0.04-3.5$ & -0.05 & Boyden (1977) \\
\hline & Gulf of St. Lawrence, Canada & $0.004-0.92$ & -0.35 & Cossa et al. (1980) \\
\hline & Baie de Bourgneuf, France & $0.05-0.2$ & -0.10 & Amiard et al. (1986) \\
\hline & Eckernförde Bight, Germany & $0.04-1.0$ & -0.07 & Fischer (1983) \\
\hline & Arctic Fjord, Greenland & $0.02-4.8$ & $0.16^{\mathrm{a}}$ & Riget et al. (1996) \\
\hline Co & Arctic Fjord, Greenland & $0.02-4.8$ & $-0.04^{\mathrm{a}}$ & Riget et al. (1996) \\
\hline $\mathrm{Se}$ & Arctic Fjord, Greenland & $0.02-4.8$ & $-0.13^{\mathrm{a}}$ & Riget et al. (1996) \\
\hline \multirow[t]{7}{*}{$\mathrm{Zn}$} & Poole Harbour, UK & $0.26-1.94$ & -0.14 & Boyden (1977) \\
\hline & Cornwall, UK & $0.04-3.5$ & -0.19 & Boyden (1977) \\
\hline & Tyre Estuary, UK & $0.02-0.7$ & 0.19 & Lobel \& Wright (1982) \\
\hline & Gulf of St. Lawrence, Canada & $0.004-0.92$ & -0.14 & Cossa et al. (1980) \\
\hline & British Columbia, Canada & $0.02-0.5$ & 0.06 & Popham \& d'Auria (1983) \\
\hline & Baie de Bourgneuf, France & $0.05-0.24$ & -0.13 & Amiard et al. (1986) \\
\hline & Arctic Fjord, Greenland & $0.02-4.8$ & $0.01^{\mathrm{c}}$ & Riget et al. (1996) \\
\hline
\end{tabular}


tions measured in the NS\&T Program. In juvenile mussels which may have higher $g$ values relative to metal efflux rate constants, $g$ should be considered in predicting metal concentrations in mussels. In the NS\&T Program, mussels $(5$ to $6 \mathrm{~cm}$ ) are sampled during winter (November to March) to avoid the possible effect of spawning on contaminant concentration in mussel tissues. During these periods mussels may also exhibit slow growth (tissue weight) due to low temperature and limited food supply (Bayne \& Worrall 1980). Under such circumstances metal concentration in tissues is less likely to be affected by mussel growth.

Different allometric patterns have been found for mussels in the field, depending on season, location, reproductive condition of mussels and other environmental conditions (Table 4). Boyden (1977) distinguished 3 patterns of metal allometry (metal concentration vs tissue weight) in marine molluscs. In some cases b values were not significantly different from 0 (typically ranging from -0.1 to 0.1 ) and metal concentration in tissues was therefore independent of size. A second pattern showed $\mathrm{b}$ values averaging -0.23 (ranging from -0.1 to -0.3 ), where metal concentration decreased with size. In a few samples b was $>0.3$, and metal concentration increased with size. All 3 patterns were observed for $\mathrm{Cd}$ and $\mathrm{Zn}$. For any allometric pattern, b values for individual metals can vary appreciably between locations and seasons (Langston \& Spence 1995). Riget et al. (1996) recorded a very high b value (0.16) for $\mathrm{Cd}$ in mussels collected from a Greenland fjord, but found mean b values not different from zero for $\mathrm{Zn}$ and possibly $\mathrm{Co}_{0}$, indicating that $\mathrm{Zn}$ and $\mathrm{Co}$ concentrations in mussels were independent of body size.

The mechanisms underlying the allometry of metal concentration in bivalve tissues are not clearly addressed in these field studies. The kinetic model is invaluable in diagnosing processes controlling metal allometry in aquatic organisms. Our study suggests that many biological factors, such as the $\mathrm{AE}, k_{\mathrm{u}}, k_{\mathrm{e}}$, and $I R$, are responsible for the allometry observed in nature. Specifically, the higher $k_{u}$ and IR in smaller individuals result in greater metal influx from both the dissolved and food ingestion pathways, and therefore increased influx rates should be accompanied by an increase in growth in smaller mussels. Any changes in these physiological parameters will result in a different outcome of metal allometry.

For Co, positive values of $\mathrm{b}$ are predicted when mussels have high growth rates (e.g. $g>0.04 \mathrm{~d}^{-1}$ for juvenile mussels), primarily as a result of a 1.5- to 2-fold increase in Co AE in larger mussels. Riget et al. (1996) indicated that $b$ values for $C o$ were either negative or close to zero in Arctic mussels. These values are predicted by our model when mussels have a low $g$. which often may be the case for mussels in Arctic waters. For
$\mathrm{Cd}, \mathrm{Se}$, and $\mathrm{Zn}$, the predicted $\mathrm{b}$ values range between -0.3 and 0 when $g$ values are between 0.02 and $0.12 \mathrm{~d}^{-1}$ for juvenile mussels; these predictions are consistent with most field measurements. Several field studies also measured a positive allometry for $\mathrm{Cd}$ and $\mathrm{Zn}$ in mussels (Table 4; Lobel \& Wright 1982, Riget et al. 1996), which is not predicted by our model. The kinetic model indicates that a positive allometry would occur for Se and $\mathrm{Zn}$ only when $g$ is much higher in juvenile mussels (e.g. $>0.15 \mathrm{~d}^{-1}$ ). Our model cannot account for the positive allometry of $\mathrm{Cd}$ in slowly growing Arctic mussels (Riget et al. 1996). It is possible that the low temperature in these waters may affect the allometry of $\mathrm{AE}, k_{\mathrm{u}}, k_{\mathrm{e}}$ and IR, leading to a positive allometry for $\mathrm{Cd}$. For example, $g$ can probably be ignored in these regions due to the very slow growth of mussels, thus significantly higher efflux in smaller individuals may result in a lower $\mathrm{Cd}$ concentration compared to larger individuals.

Given the experimentally determined allometry of metal $\mathrm{AE}, k_{\mathrm{u}}, k_{\mathrm{e}}$ and IR, our model predicts that b values are significantly influenced by $g$. No single value of $b$ is likely for a specific metal, as indicated by Boyden (1977). The numerous environmental and biological factors (e.g. temperature, salinity, season, light, food supply, water depth, intraspecific competition; Seed \& Richardson 1990) affecting mussel growth will also influence metal allometry. For example, sampling mussels at different seasons may cause a change in b values due to variation in $g$. Seasonal differences in growth rate appear to interact with size-dependent differences in metal uptake, as shown for $\mathrm{Cu}$ and $\mathrm{Ag}$ in the clam Macoma balthica by Strong \& Luoma (1981). They found a negative correlation in the summer when the growth of the clams was slowest and a positive correlation during the growing season, observations that are consistent with our model prediction that $b$ increases with $g$. Similarly, Goede et al. (1993) demonstrated that the decrease of Se concentration in mussels with length was less obvious or absent when the mussels were collected in late spring and summer in the Dutch Wadden Sea when growth rate was highest.

It should be emphasized that all the parameters identified in the kinetic model are not constant under field conditions. Metal AE is a function of food concentrations and food composition (Wang et al. 1995, Wang $\&$ Fisher 1996a). Metal $k_{\mathrm{u}}$ can be affected by the biological conditions (e.g. metallothionein induction), the physico-chemical behavior of the metal (e.g. metal speciation), and other environmental conditions (salinity, dissolved organic carbon concentration). Mussel IR values are dependent on food concentration, feeding selectivity and season (Bayne \& Newell 1983). Metal $K d$ s in seston can fluctuate by up to an order of magnitude, although the $K d s$ based on weak acid (e.g. $0.5 \mathrm{~N}$ 
HCl) extraction appear to be rather constant (S. Sañudo-Wilhelmy pers. comm). Variations of these parameters may have a considerable bearing on metal allometry. Furthermore, application of the kinetic model can be complicated by spawning, during which there is negative growth in somatic tissue.

Wang et al. (1996) quantified the relative importance of metal uptake from the dissolved phase and particulate ingestion pathway in mussels. Uptake from each source depended greatly on metal AE and $K d$ on food particles. The kinetic model is probably the most realistic approach in separating uptake pathways in aquatic organisms because it can incorporate variations in each physiological and geochemical factor affecting metal uptake (Wang \& Fisher 1997). Model calculations in this study are comparable to those in Wang et al. (1996), where only AE, $K d, k_{u}$, and IR were shown to influence the proportion of uptake from the dissolved phase and from food. Thus, when the $k_{\mathrm{u}}$ scales in a similar allometry as IR, the relative importance of dissolved uptake remains constant among different-sized animals.

\section{Allometry of metal specific physiological parameters}

AEs for each trace element measured in this study were within the range reported previously for mussels feeding on diverse food particles, with highest values for Se followed by $\mathrm{Cd}>\mathrm{Co}>\mathrm{Zn}$ (Wang \& Fisher 1996a). The effects of mussel body size on Se and $\mathrm{Zn}$ AEs are consistent with observations for $C$ assimilation in mussels (Widdows 1978, Winter 1978). In addition, similar allometric responses to these metals were observed in mussels feeding on the 2 diatom diets (Thalassiosira pseudonana and Phaeodactylum tricornutum). Because all 4 trace elements were fed simultaneously to the mussels, any differences in the fate of the trace elements cannot be attributed to experimental variability in food or mussels.

The variation in Co AEs with mussel size may have reflected the redox behavior of Co (Lee \& Fisher 1993) within the mussel's gut. Specifically, we speculate that the shorter diffusion distance in smaller individuals may result in a more oxygenated gut than in larger individuals. Thus, in smaller mussels more Co would be present as $\mathrm{Co}^{3+}$ which can scavenge onto unassimilated particles that are egested as feces. In larger mussels, with a presumably more anoxic gut, $\mathrm{Co}^{3+}$ may be reduced to the more soluble $\mathrm{Co}^{2+}$ which can then be assimilated by mussels after crossing the gut epithelium. Differences in Co assimilation among the 3 body sizes were mainly associated with the second phase of digestion (intracellular digestion), suggesting that digestion in larger individuals might be oxygen limited.
Differences in $\mathrm{Cd}$ assimilation among the 3 body sizes were largely evident during the first few hours of digestion, during which $\mathrm{Cd}$ desorption from ingested food particles within the gut probably occurred. The assimilation efficiency of $\mathrm{Cd}$ in Mytilus edulis is highly dependent on its desorption from ingested diatoms or sediment particles at pH 5.5 (Wang \& Fisher 1996b, Gagnon \& Fisher 1997), a gut pH typical of marine bivalves (Owen 1974).

Metal uptake in mussels from the dissolved phase was probably dominated by a passive and/or facilitated diffusion (Wang et al. 1996). Because only 3 body sizes were considered in this study, it is difficult to conclude whether allometry of metal uptake from the dissolved phase is controlled by a change in gill surface area. The small sample size also increased the confidence interval of the $b$ coefficients. However, the 2 -fold variation of the coefficient describing the power function of $k_{\mathrm{u}}$ and tissue dry weight among the 4 trace elements $(-0.3$ to -0.57$)$ indicates that gill surface area is not solely responsible for the observed allometry. For $\mathrm{Cd}$ and $\mathrm{Zn}$, it is likely that metabolic processes (e.g. clearance rate, protein ligand) control the allometry. Metal transport across the membranes may be dominated by an initial binding with protein ligands within the membrane before being released intracellularly (Wang et al. 1996, Wang \& Fisher unpubl.). Newman \& Mitz (1988) also found a size-dependence of $k_{u}$ for $\mathrm{Zn}$ in mosquitofish Gambusia holbrooki with a simple power function (b increased from -0.32 after $10 \mathrm{~d}$ exposure to -0.53 after $350 \mathrm{~d}$ exposure), but a clear relationship was not found for Hg uptake (Newman \& Doubet 1989). Newman \& Heagler (1991) speculated that both metabolic rate and gill surface area:volume ratio in fish may determine these relationships for $\mathrm{Zn}$ accumulation. In a study of PCB (polychlorinated biphenyl) accumulation in different-sized mussels, Gilek et al. (1996) similarly showed that uptake rate decreased significantly with body weight with a power function of -0.32 . They also showed that the weightspecific gill surface area decreased with body weight with a power function of -0.32 , suggesting that variations in the gill surface area were responsible for the different uptake rates displayed by different-sized mussels. If this weight-specific gill surface area to body weight relationship is also applicable to our study, it can be concluded that change in gill surface area can account for the allometry of uptake of dissolved Se and Co (which had a comparable power function of -0.3 ).

Metal efflux rate constants in mussels measured in this study are comparable to previous measurements (0.01 to $0.03 \mathrm{~d}^{-1}$; Wang et al. 1996). Our study indicates that $k_{e}$ remained constant or decreased slightly with body size (except for $\mathrm{Cd}$ ). In a previous study, efflux rate was unaffected by the route (food vs dissolved 
uptake) or duration of exposure (Wang et al. 1996). Comparable depuration rates of PCB among different body sizes were also demonstrated in mussels after 24 h feeding (Gilek et al. 1996). However, several other studies have shown that efflux rate constants of both inorganic and organic contaminants were inversely correlated with body size in aquatic animals (Landrum 1988, Newman \& Mitz 1988). In mussels, only Cd exhibited a decline in efflux rate with increasing body size. The biochemical mechanisms underlying the variation in Cd release from different-sized mussels remains unknown. Our study also suggests that physiological efflux is not related to the assimilation of metal from food. For example, there was no size-dependence on Co efflux rate, but the larger individuals generally had a higher AE. Smaller mussels generally had a higher $\mathrm{AE}$ for $\mathrm{Cd}$ but had a higher efflux rate for this metal. In the long-term efflux experiments, most $(>83 \%)$ of the $\mathrm{Cd}$ was partitioned in the slowest exchanging pool, thus the assimilability of $\mathrm{Cd}$ is difficult to determine from these $7 \mathrm{~d}$ food uptake experiments.

In conclusion, this study demonstrated that major physiological parameters such as $\mathrm{AE}, k_{\mathrm{u}} \mathrm{IR}$, and $k_{\mathrm{e}}$ in mussels are directly dependent on body size. Any changes in these parameters will affect the allometry of metal accumulation in marine mussels. The bioenergetic-based kinetic model can be used to predict the allometry of metal accumulation by incorporating major physiological processes involved in metal bioaccumulation. The growth rate constant is critical for determining metal allometry in mussels. With an increase in mussel growth rate, metal allometry is less dependent on body size.

Acknowledgements. We thank 3 anonymous reviewers for many constructive comments on the manuscript. This study was supported by grant No. N000149511229 from the US Office of Naval Research, grants NA90AADSG078 and NA46RG0090 from the NY Sea Grant Institute, and by a grant from the National Association of Photographic Manufacturers to N.S.F. This is MSRC contribution number 1060

\section{LITERATURE CITED}

Amiard J, Amiard-Triquet C, Berthet B, Metayer C (1986) Contribution to the ecotoxicological study of cadmium. lead, copper and zinc in the mussel Mytilus edulis. I. Field study. Mar Biol 90:425-431

Bayne BL, Newell RC (1983) Physiological energetics of marine molluscs. In: Wilbur KM, Saleuddin AS (eds) The Mollusca, Vol 4. Academic Press, New York, p 407-515

Bayne BL, Worrall CM (1980) Growth and production of mussels Mytilus edulis from two populations. Mar Ecol Prog Ser 3:317-328

Borchardt T, Burchert S, Hablizel H, Karbe L, Zeltner R (1988) Trace metal concentrations in mussels: comparison between estuarine, coastal and offshore regions in the southeastern North Sea from 1983 to 1986. Mar Ecol Prog Ser 42:17-31

Boyden CR (1974) Trace element content and body size in molluscs. Nature 251:311-314

Boyden CR (1977) Effect of size upon metal content of shellfish. J Mar Biol Assoc UK 57:675-714

Clausen I, Riisgård HU (1996) Growth, filtration and respiration in the mussel Mytilus edulis: no evidence for physiological regulation of the filter-pump to nutritional needs. Mar Ecol Prog Ser 141:37-45

Cossa D, Bourget E, Pouliot D, Piuze J, Chanut JP (1980) Geographical and seasonal variations in the relationship between trace metal content and body weight in Mytilus edulis. Mar Biol 58:7-14

Fischer $H$ (1983) Shell weight as an independent variable in relation to cadmium content of molluscs. Mar Ecol Prog Ser 12:59-75

Gagnon C, Fisher NS (1997) The bioavailability of sedimentbound $\mathrm{Cd}, \mathrm{Co}$, and Ag to the mussel Mytilus edulis. Can J Fish Aquat Sci 54:147-156

Gilek M, Björk M, Näf C (1996) Influence of body size on the uptake, depuration, and bioaccumulation of polychlorinated biphenyl congeners by Baltic Sea blue mussels, Mytilus edulis. Mar Biol 125:499-510

Goede AA, Wolterbeek HT, Koese MJ (1993) Selenium concentrations in the marine invertebrates Macoma balthica, Mytilus edulis, and Nereis diversicolor. Arch Environ Contam Toxicol 25:85-89

Harris JE, Fabris GJ, Statham PJ, Tawfik F (1979) Biogeochemistry of selected heavy metals in Western Port, Victoria, and use of invertebrates as indicators with emphasis on Mytilus edulis planulatus. Aust J Mar Freshwat Res 30: $159-178$

Jørgensen CB (1996) Bivalve filter feeding revisited. Mar Ecol Prog Ser 142:287-302

Landrum PF (1988) Toxicokinetics of organic xenobiotics in the amphipod, Pontoporeia hoyi, role of physiological and environmental variables. Aquat Toxicol 12:245-271

Langston WJ, Spence SK (1995) Biological factors involved in metal concentrations observed in aquatic organisms. In: Tessier A, Turner DR (eds) Metal speciation and bioavailability in aquatic systems. John Wiley \& Sons, Chichester, p $407-478$

Lee BG, Fisher NS (1993) Microbially mediated cobalt oxidation in seawater revealed by radiotracer experiments. Limnol Oceanogr 38:1593-1602

Lobel PB, Wright DA (1982) Relationship between body zinc concentration and allometric growth measurements in the mussel, Mytilus edulis. Mar Biol 66:145-150

Newman M, Doubet D (1989) Size-dependence of mercury(II) accumulation kinetics in the mosquitofish Gambusia affinis (Baird and Girard). Arch Environ Contam Toxicol 18: $819-825$

Newman MC, Heagler MG (1991) Allometry of metal bioaccumulation and toxicity. In: Newman $\mathrm{MC}$, McIntosh $\mathrm{AW}$ (eds) Metal ecotoxicology: concepts and applications. Lewis Publishers, Chelsea, MI, p 91-130

Newman MC, Mitz SV (1988) Size dependence of zinc elimination and uptake from water by mosquitofish Gambusia affinis (Baird and Girard). Aquat Toxicol 12:17-32

O'Connor TP, Cantillo AY, Lauenstein GG (1994) Monitoring of temporal trends in chemical contamination by the NOAA national status and trends mussel watch project. In: Kramer KJM (ed) Biomonitoring of coastal waters and estuaries. CRC Press, Boca Raton, FL, p 29-50

Owen (1974) Feeding and digestion in the Bivalvia. Adv Comp Physiol Biochem 5:1-35 
Phillips DJH (1976) The common mussel Mytilus edulis as an indicator of pollution by zinc, cadmium, lead and copper. I. Effects of environmental variables on uptake of metals. Mar Biol 38:59-69

Phillips DJH (1980) Quantitative aquatic biological indicators. Applied Science Publishers, London

Popham JD, d'Auria JM (1983) Combined effect of body size, season, and location on trace element levels in mussels (Mytilus edulis). Arch Environ Contam Toxicol 12:1-14

Riget $F$, Johansen P, Asmund G (1996) Influence of length on element concentrations in blue mussels (Mytilus edulis). Mar Pollut Bull 32:745-751

Seed R, Richardson CA (1990) Mytilus growth and its env1ronmental responsiveness. In: Stefano GB (ed) Neurobiology of Mytilus edulis. Manchester Univ Press, Manchester, $\mathrm{p} 1-37$

Strong CR, Luoma SN (1981) Variations in the correlation of body size with concentrations of $\mathrm{Cu}$ and $\mathrm{Ag}$ in the bivalve Macoma balthica. Can J Fish Aquat Sci 38:1059-1064

Wang WX. Fisher NS (1996a) Assimilation of trace elements and carbon by the mussel Mytilus edulis: effects of food composition. Limnol Oceanogr 41:197-207

Wang WX, Fisher NS (1996b) Assimilation of trace elements by the mussel Mytilus edulis: effects of diatom chemical composition. Mar Biol 125:715-724

Wang WX. Fisher NS (1997) Modeling metal bioavailability for

Editorial responsibility: Otto Kinne (Editor),

Oldendorf/Luhe, Germany marine mussels. Rev Environ Contam Toxicol 151:39-65

Wang WX, Fisher NS, Luoma SN (1995) Assimilation of trace elements ingested by the mussel Mytilus edulis: effects of algal food abundance. Mar Ecol Prog Ser 129:165-176

Wang WX, Fisher NS, Luoma SN (1996) Kinetic determinations of trace element bioaccumulation in the mussel Mytilus edulis. Mar Ecol Prog Ser 140:91-113

Wang WX, Griscom SB, Fisher NS (1997) Bioavailability of Cr(III) and CriVI) to marine mussels from solute and particulate pathways. Environ Sci Technol 31:603-611

Ward JE, Targett NM (1989) Influence of marine microalgal metabolites on the feeding behavior of the blue mussel Mytilus edulis. Mar Biol 101:313-321

Widdows J (1978) Combined effects of body size, food concentration and season on the physiology of Mytilus edulis J Mar Biol Assoc UK 58:109-124

Widdows J, Fieth P. Worrall CM (1979) Relationships between seston, available food and feeding activity in the common mussel Mytilus edulis. Mar Biol 50:195-207

Widdows J, Nasci C, Fossato VU (1997) Effects of pollution on the scope for growth of mussels (Mytilus galloprovincialis) from the Venice Lagoon, Italy. Mar Environ Res 43:69-79

Winter JE (1978) A review on the knowledge of suspensionfeeding in lamellibrachiate bivalves, with special reference to artificial aquaculture systems. Aquaculture 13: $1-33$

Submitted: July 2, 1997; Accepted: October 21, 1997

Proofs received from author(s): December 22, 1997 